\title{
Erratum to: Genomic classification of betanodavirus by molecular phylogenetic analysis of the coat protein gene
}

\author{
C. P. Binesh • C. Greeshma $\cdot$ K. P. Jithendran
}

Published online: 18 June 2013

(C) Springer-Verlag Wien 2013

\section{Erratum to: Arch Virol}

DOI 10.1007/s00705-012-1549-7

Unfortunately, in the original publication an author in the author group and the acknowledgement section were missed. The correct author group and acknowledgements are given below:

C. P. Binesh, C. Greeshma and K. P. Jithendran

Acknowledgments The authors are grateful to the Director, Central Institute of Brackishwater Aquaculture, Chennai (India) for providing facilities to carry out the work and Department of Biotechnology (Ministry of Science and Technology, New Delhi, India) for funding the study in part under the project No. BT/PR-8205/AAQ/03/303/ 2006.

The online version of the original article can be found under doi:10.1007/s00705-012-1549-7.

C. P. Binesh $(\square)$

Sacred Heart College, Thevara, Cochin 682013, Kerala, India

e-mail: bineshkanayi@gmail.com

C. Greeshma

Department of Life Sciences, Calicut University, Thenjippalam,

Malappauram, Kerala, India

e-mail: greeshmakongatta@gmail.com

\section{K. P. Jithendran}

Aquatic Animal Health and Environment Division,

Central Institute of Brackishwater Aquaculture,

75, Santhome High Road, Chennai 600 028, India 